\title{
Additions and amendments to the myxomycetes in Finland
}

\author{
MARJA HÄRKÖNEN, TARJA UKKOLA AND KATI PEKKALA
}

\begin{abstract}
HÄRKÖNEN, M., UKKOLA, T. \& PEKKALA, K. 1999: Additions and amendments to the myxomycetes in Finland. - Karstenia 39:49-57. Helsinki. ISSN 0453-3402

The following species of myxomycetes are reported for the first time from Finland: Arcyria affinis Rostaf., A. globosa Schwein., Colloderma oculatum (Lippert) G. Lister, Cribraria violacea Rex, Dianema harveyi Rex, Diderma asteroides (Lister \& G. Lister) G. Lister, Hemitrichia leiotricha (Lister) G. Lister, Lamproderma gulielmae Meyl., Licea castanea G. Lister, L. marginata Nann.-Bremek., L. operculata (Wingate) G. W. Martin, Physarum bitectum G. Lister, and P. gyrosum Rostaf. All the specimens of Fuligo septica sensu lato in the Finnish collections have been re-examined, and two additional species, Fuligo leviderma H. Neubert, Nowotny \& K. Baumann and F. luteonitens L. G. Krieglst. \& Nowotny, are recognized and illustrated. The second record of the rare species Didymium obducens P. Karst. in Finland is reported and the plasmodium illustrated. The third report of Cribraria microcarpa (Schrad.) Pers. emend. Nann.-Bremek confirms the presence of that species in Finland. The known biota of myxomycetes in Finland now includes 191 species.
\end{abstract}

Marja Härkönen, Tarja Ukkola and Kati Pekkala, Department of Ecology and Systematics, P.0. Box 7, FIN-00014 University of Helsinki, Finland.

A checklist of the Finnish myxomycetes was compiled by Härkönen (1979b), with two supplements (Härkönen 1981, 1988). The present paper reports 15 species of myxomycetes new to Finland. The specimens examined are deposited in the Finnish herbaria: $\mathrm{H}$ (University of Helsinki), JOE (University of Joensuu), KUO (Kuopio Museum of Natural History), and OULU (University of Oulu). A short description of each species is presented, based on our own observations and measurements of the listed material. Spore sizes are measured excluding the ornamentation.

In addition to the new records, supplementary data on other members of the Finnish myxomycetes are given. A rare species, Didymium obducens (syn. D. fulvum Sturgis) has been found for the second time, and Cribraria microcarpa for the third time from Finland. The presence of the latter species among the Finnish myxomycete bi- ota has been somewhat uncertain (see Hintikka 1920, Härkönen 1979b).

All specimens of Fuligo deposited in the Finnish herbaria were checked and compared with descriptions of Fuligo leviderma $\mathrm{H}$. Neubert, Nowotny \& K. Baumann, and F. luteonitens L. G. Krieglst. \& Nowotny in Neubert et al. (1995).

The species are listed alphabetically. The collectors' names are abbreviated as follows: $T A=$ Teuvo Ahti, $V H a$ $=$ Veli Haikonen, $H H=$ Harri Hautala, $M-L H=$ MarjaLiisa Heinonen, $P H=$ Pekka Heinonen, $T J H=$ T.J. Hintikka, $V H=$ Veikko Hintikka, $I H=$ Irja Huuskonen, $C$ $A H=$ Carl-Adam Hæggström, $M H=$ Marja Härkönen, $E H=$ Ernst Häyren, $P A K=$ P.A. Karsten, $M K=$ Markku Kirsi, $M K o=$ Mauri Korhonen, $M K u=$ Matti Kulju, $M L=$ Matti Laurila, $N M=$ Nicken Malmström, $A M=$ Annemari Markkola, $J M=$ Jari Metso, $W N y b=$ Wolmar Nyberg, $W N y l=W$. Nylander, $E O=$ Esteri Ohenoja, $M O=$ Martti Ohenoja, $A-L P=$ Anna-Liisa Paulus, $K P=$ Kati Pekkala, $J P=$ Jens Petersen, $A R=$ Aarre Rauhala, $P R=$ Rertti Renvall, $P S=$ Pertti Salo, $U N-S=$ Ulla Nummela- 
Salo, VAS $=$ V.A. Seppälä, $K T=$ Kalevi Takala, $T U=$ Tarja Ukkola, $T U l=$ Tauno Ulvinen, $R V=$ Risto Virtanen, and $P-G W=$ Per-Gustav Wikström.

The biogeographic provinces in Finland are delimited and named according to Hansen \& Knudsen (1992).

Arcyria affinis Rostaf. emend. Nann.-Bremek. Specimens examined: Uusimaa. Espoo: Nuuksio National Park, on a Betula log (mixed with Physarum leucophaeum Fr. and Trichia varia (Pers.) Pers.), 29.IX.1994 KP $900(\mathrm{H})$; Luukkaa, on a fallen hard Betula trunk, 2.VII.1998 TU $712(\mathrm{H})$.

Sporangia in groups, stipitate, cylindrical, initially up to $2 \mathrm{~mm}$ tall, expanding up to $7 \mathrm{~mm}$ long and about 0.4 $\mathrm{mm}$ in diameter; dark red when fresh, changing to redbrown with age. Stalk about $0.4 \mathrm{~mm}$ long, dark brown, shiny, filled with spore-like cells. Hypothallus membranous, shiny. Peridium early evanescent from the upper parts, occasionally some flakes remain attached to capillitium; peridial calyculus deep, goblet-shaped, often asymmetrical, plicate, shiny, pale reddish in transmitted light, inner side densely dotted with warts which often unite with ridges into an irregular reticulum. Capillitium elastic, expanding longitudinally, attached to the stalk apex only and easily blowing away, threads forming a fairly wide-meshed net, ornamented with warts, spines, half-rings, and ridges which may unite to form reticulation, $3-7(-9) \mu \mathrm{m}$ in diameter. Spores dark red to redbrown in mass, nearly colourless in transmitted light, globose, minutely warted with some groups of larger warts, 6.5-7.1-7.5(-8) $\mu \mathrm{m}$ in diameter.

Arcyria affinis is a variable species, the circumscription of which here follows NannengaBremekamp $(1968,1991)$. It is rather common on decaying wood, and has been reported, from e.g., Europe, North and South America, Australia, New Zealand, India and Japan (Lakhanpal \& Mukerji 1981, Nannenga-Bremekamp 1991, Mitchell 1992, 1995, Neubert et al. 1993, Yamamoto 1998).

\section{Arcyria globosa Schwein.}

Specimen examined: Varsinais-Suomi. Vihti: Nuuksio National Park, on a fallen twig of Picea abies, 5.X.1994 KP1431 (H).

Sporangia scattered, stipitate, pale grey, globose, 0.6 $0.7 \mathrm{~mm}$ tall, $0.5 \mathrm{~mm}$ in diameter. Stalk $0.1 \mathrm{~mm}$ long, yellowish-brown, slightly shiny. Peridium evanescent in the upper half, lower half remaining as a deep, bowlshaped calyculus, the inner side of which is minutely warted. Capillitium unelastic, theads 3-6 $\mu \mathrm{m}$ in diameter, forming a net with quite a few free, clavate ends, threads ornamented with spines, and in some places with irregular reticulation. Spores pale grey in mass, nearly colourless in transmitted light, globose, minutely warted with some scattered groups of warts, $7.0-\underline{7.5}-8.5 \mathrm{in} \mathrm{di}-$ ameter.

The specimen is very scanty, with only two sporangia. The substrate is somewhat unusual: Arcyria globosa is more common on chestnut burs and dead leaves than on conifer twigs, but Neubert et al. (1993) also mention conifer twigs as a substrate.

Colloderma oculatum (C. Lippert) G. Lister Specimen examined: Koillismaa. Salla: Värriö Strict Nature Reserve, on a decayed Picea abies spp. obovata (mixed with a badly weathered Cribraria sp.), 20.VIII.1989 PR 1847 (KUO).

Sporangia scattered, sessile, spherical, $0.3-0.4 \mathrm{~mm}$ in diameter, dark olive-brown or nearly black, slightly shiny. Peridium double, outer layer dark when dry, deposited with granules, olivaceous in transmitted light, inner layer membranous, firmly appressed to the outer layer. Columella absent. Capillitial threads rising from the base of the sporangium, thin, sparsely branching with some interconnections, pale, tips colourless. Spores dark brown in mass, brown in transmitted light, globose to subglobose, densely spiny, 10-10.9-12 $\mu \mathrm{m}$ in diameter.

According to Martin and Alexopoulos (1969) and Nannenga-Bremekamp (1991), Colloderma oculatum may also be short-stalked or plasmodiocarpous. The outer layer of the peridium is thick, gelatinous when moist. The Finnish specimen is very scanty, consisting of only two mature sporangia.

Colloderma oculatum has been reported from many European countries, the U.S.A. and Japan (Martin \& Alexopoulos 1969, Yamamoto 1998).

Cribraria microcarpa (Schrad.) Pers. emend Nann.-Bremek.

Specimen examined: Varsinais-Suomi. Kimito: Kuggböle, in moist chamber culture on a well-decayed Betula $\log$ (on wood), 29.IV.1999 P-GW 5451 (H).

Sporangia scattered, stalked, delicate, globose, nodding, ochraceous yellow; total height of 1-4 mm, 0.1$0.3 \mathrm{~mm}$ in diameter. Stalk long, slender, dark red-brown, shiny, tapered to the apex, which is paler, including dark granules. Hypothallus small and brown. Basal part of peridium remains as a small disc from which the threads of the peridial net arise, disc filled with radially arranged dictydine granules, $0.5-2 \mu \mathrm{m}$ in diameter. Peridial net regular, meshes mostly rectangular, occasionally triangular, nodes dark, round or roundish, some also elongated, clearly thickened, filled with dark dictydine granules, dark or ochraceous in transmitted light; connecting threads thin, pale honey yellow in transmitted light, mostly about $1 \mu \mathrm{m}$ in diameter, without dictydine granules and with only a few free ends from the nodes. Spores ochraceous yellow in mass, pale yellow in transmitted light, globose, minutely warted, $6-\underline{6.6}-7 \mu \mathrm{m}$ in diameter.

Cribraria microcarpa is a small, delicate species, easily overlooked in the field. It is probably more common in Finland than the number of collections indicate. Karsten $(1868,1879)$ reported two collections: one from Etelä-Häme, Mustiala, 
Pähkijärvi (as Dictydium microcarpum Schrad.), the other from Varsinais-Suomi, Merimasku. There is no specimen left of the first collection, but the latter collection (11.VII.1860 P.A. Karsten) is deposited in H. Except for one fairly badly preserved sporangium, only stalks are left in the specimen. Since there has been no proper collection of $C$. microcarpa in Finland, we include here a description based on this material.

\section{Cribraria violacea $\mathrm{Rex}$}

Specimen examined: Varsinais-Suomi. Kimito: Orrnäs, in moist chamber culture on bark of a living apple tree (Malus domestica), 12.IV.1999 P-GW 5444 (H).

Sporangia scattered or gregarious, stalked, subglobose to obovoid, dark violet, shiny; total height of 530-830 $\mu \mathrm{m}, 110-130 \mu \mathrm{m}$ in diameter. Stalk long, slender, tapering to the apex, dark violet to nearly black, red-brown enclosing refuse matter at the lower part in transmitted light, the apical part with violet tints to clearly violet and filled with dark violet granules. Hypothallus inconspicuous. Peridial basal part persisting as a deep calyculus, $1 / 2-2 / 3$ of the cavity of the sporotheca, with dark violet, shiny rim having shallow teeth; filled with dark violet, round dictydine granules mostly $0.5-1.0 \mu \mathrm{m}$ in diameter, but up to $1.5 \mu \mathrm{m}$. Peridial net open, nodes flat, irregular in shape and size, enclosing dark violet, round granules, same size as in the calyculus; connecting threads slender, without dictydine granules. Spores violet in mass, lilac in transmitted light, globose or occasionally slightly crenulate in optical section, very minutely warted, 7.0-7.6-8.0 $\mu \mathrm{m}$ in diameter.

Cribraria violacea is widespread in the world, but is especially common in the tropics.

\section{Dianema harveyi Rex}

Specimen examined: Perä-Pohjanmaa. Keminmaa: Kallinkangas, on decayed wood (mixed with Diderma umbilicatum Pers. var. umbilicatum), 14.X.1998 HH (OULU).

Sporangia scattered or in small groups, sessile, pulvinate, round, roundish or elliptical when seen from above, occasionally umbilicate, ochraceous brown, iridescent, $0.2-1.5 \mathrm{~mm}$ in diameter. Capillitium of stout or slightly undulating, smooth threads arising from the base, connected to the peridium, threads sparsely forked, $1-2 \mu \mathrm{m}$ in diameter, yellow in transmitted light. Spores ochraceous in mass, pale yellow in transmitted light, globose, minutely spinulose, $8-\underline{8.8}-10(-11) \mu \mathrm{m}$ in diameter.

Dianema harveyi is a rather rare species, known from the U.S.A., Europe, New Zealand, and Japan (Martin \& Alexopoulos 1969, Mitchell 1992, Neubert et al. 1993, Lado 1994, Yamamoto 1998).

Diderma asteroides (Lister \& G. Lister) G. Lister Specimen examined: Varsinais-Suomi. Vihti: Nuuksio National Park, on a small, fallen twig of Picea abies, 15.X.1994 KP $1347(\mathrm{H})$.
Sporangia gregarious, sessile, subglobose, about 0.5 $1 \mathrm{~mm}$ in diameter, up to $2 \mathrm{~mm}$ when opened, dark redbrown with thin pale lines of dehiscence, shiny. Hypothallus membranous, brown. Peridium double, outer layer dark red-brown, appressed to the white, calcareous inner layer, layers dehiscing together into stellate lobes. Columella absent. Capillitial threads thin, pale brown to hyaline, simple or branching and anastomosing with some interconnecting threads. Spores dark brown in mass, bright brown in transmitted light, slightly paler on one side, densely warted, (9-)9.5- $10.3-11 \mu \mathrm{m}$ in diameter.

None of the sporangia in the Finnish specimen had columella. According to the references the columella is usually present, varying from a flat thickening of the base of the sporangium to hemispherical, globose or conical; the peridium is often triple, the innermost layer being membranous, hyaline. Fructifications of Diderma asteroides may occasionally be short-stalked or plasmodiocarpous (Martin \& Alexopoulos 1969, Nannenga-Bremekamp 1991).

Diderma asteroides is widespread, but not a common species.

Didymium obducens P. Karst. Figs. 1-2

Specimens examined: Varsinais-Suomi. Kimito: Rugnola, Österängskullan, on mosses growing on a decayed Populus tremula stump, 30.VIII.1998 P-GW 5379, 31.VIII $1998 P-G W 3581$; on litter, 31.VIII.1998 P-GW 5382, 06.IX.1998 P-GW 5397, 5398. (H).

Didymium obducens was described as a new species by Karsten (1868). The holotype is from Etelä-Häme: Tammela, Mustiala, Myllyperä, at base of Alnus incana, X.1866 P.A. Karsten 2035 (H). Later on, Karsten (1879) treated it as a variety of Didymium crustaceum. Härkönen (1979a) examined the holotype and concluded that $D$. crustaceum and $D$. obducens are closely related but not conspecific. In Martin \& Alexopoulos (1969), Karsten's specimen keys to Didymium fulvum Sturgis. Härkönen (1979a) studied its type specimen and found it to be conspecific with $D$. obducens. The plasmodium was unknown, but now we can describe it as an ochre yellow phaneroplasmodium (Fig. 1).

In addition to Finland $D$. obducens has been reported from Italy, Japan, Pakistan, India, and the U.S.A. (Härkönen 1979a, Lakhanpal \& Mukerji 1981, Lado 1994, Neubert et al. 1995, Yamamoto 1998).

Fuligo leviderma $\mathrm{H}$. Neubert, Nowotny \& K. Baumann Figs. 5, 6, 9

Specimens examined: Varsinais-Suomi. Kimito: Wijk, on a moss-covered stump, 02.X.1977 P-GW (H). 
Koski: Hongisto, on a fairly rotten stump of Populus tremula, 28.VIII.1995 M-LH \& PH 483-95F (TUR). Uusimaa. Helsinki: Sörnäinen, 1860 WNyl; Helsinki, on a stump, 22.X.1895 collector unknown (H). Espoo: Isohuopalahti, on a decayed Betula stump, 25.XII.1972 $C$ - $A H$; Nuuksio National Park, on a big $\log$ of $P$. tremula, 16.VIII.1994 KP 13; on a Pinus sylvestris log, 16.VIII.1994 KP 75 (H). Kauniainen: 30.VIII.1941 Wnyb (H). Porvoo: IX.1928 WNyb; 26.X.1934 NM (H). Vantaa: Hämeenkylä, Västra, on living straw, 12.IX.1974 MKo (H). Nurmijärvi: Klaukkala, S slope of Tornimäki, on a dead stub of P. tremula, 14.I.1983 TA 41190 \& B. Tan (H). Etelä-Häme. Tammela: Mustiala, 23.VIII.1872 PAK $(\mathrm{H})$. Janakkala: on a decayed trunk of Betula, 16.IX.1914 VAS (H). Heinola: Tommola, 1953 $A R(\mathrm{H})$. Lammi: Evo, Vahtervehmaa, on a rotten log of Betula, 12.IX.1975 MH 720; virgin forest of Kotinen, on decayed wood, 14.IX.1979 MH 1619; Biological Station, on bark of a big, fallen deciduous tree, 14.IX.1993 MH 3885; on Trametes zonata growing on a fallen $P$. tremula behind the station, 30.VIII.1976 MH 863. (H). Padasjoki: Vesijako Nature Park, on bark of a dead Betula, 21.IX.1993 MH 3900. (H). Etelä-Savo. Pertunmaa: Seppälänjoki, on bark of a P. tremula, 29.III.1986 VHa 6939 (H). Pohjois-Savo. Iisalmi: Kirkkosalmi, Leppiranta, 11.IX.1965 IH (OULU). Joroinen: 1914 TJH (H). Pohjois-Karjala. Tuupovaara: on E shore of Lastujärvi, on a decayed stump of $P$. tremula, 30.VIII.1967 KT 4476 (OULU). Eno: Rasivaara, Valkealampi South, on a fallen corticated Betula, 7.IX.1996 MK 96-196 (JOE). Ilomantsi: 22.VIII. 1999 $J P$, 28.VIII.1996 A-LP, 23 IX.1997 MK 97-126 (JOE). Joensuu: Niinivaara, on a dead $P$. tremula, 1.XI.1998 MK 98-516 (JOE). Liperi: Myllylampi, on Alnus, 27.X.1996 MK 96-309; on a decaying Betula, 04.X.1998 MK 98-454. (JOE). Keski-Pohjanmaa. Kälviä: on SW side of Maajärvenräme, on a stump of $P$. tremula (?), 8.V.1967 KT 4145 (OULU). Kärsämäki: Venetpalo, Lapinniemi, on a dead, standing $P$. tremula, 15.I.1992 MKu (OULU). Oulun Pohjanmaa. Oulu: Hietasaari, Kansankenttä, on a decayed stump, 07.IX.1966 Tul (OULU). Haukipudas: Kalimenkylä, on a stump, 8.IX.1968 TUl; Korvenkylä, on SW shore of Kalimenoja, on moss covering the decayed stump of $P$. tremula, and on Daedaleopsis confragosa, 05.VI.1969 MO 4; on E shore of Kalimenoja, on a decayed, mosscovered trunk of $P$. tremula, 05.VI.1969 MO 7; NE side of Kalimenoja, on twigs, 28.IX.1969 MO 16. (OULU). Kiiminki: Jääli, on a moss-covered stump of $P$. tremula, 10.V.1970 MO 8; Juuansydänmaa, on $\mathrm{S}$ side of Iso Juuankangas, on a stump, 13.IX 1989 EO. (OULU). Pudasjärvi: Puhos, on a stump of $P$. tremula, 22.IX.1995 $E O$ (OULU). Muhos: Leppiniemi, on N shore of Oulujoki river, on a fairly well-decayed Picea abies trunk, 22.IX.1998 HH (OULU). Koillismaa. Kuusamo: Oulanka National Park, on bank of Oulanka River between Petoniva and Rytilampi, on bark at base of a Populus tremula. Liikasenvaara, on the shore of Sirkkapuro, on bark of P. abies, 8.VIII.1974 TUl. Virkkula, S slope of Konttainen hill, on a stump (Betula?), 26.VIII.1979 Tul \& Co. (OULU). Posio: Livojärvi, Palokangas, on a stump of $P$. sylvestris, 05.VIII.1979 TUl (OULU). Sompion Lappi. Pelkosenniemi: Alaperä, 14.IX.1998 EO (OULU). Säynäjäjoki: Suumaanlampi, on a log of Betula lying on the ground, 23.VIII.1994 $U N-S \&$ \& 632 (OULU)

Aethalia pulvinate to hemispherical, red-brown, occasionally ochraceous brown, mostly $1.0-4.5 \times 2.0-6.5$ $\mathrm{cm}$, occasionally $7 \times 12 \mathrm{~cm}$ in diameter, $4-8(-15) \mathrm{mm}$ thick. Hypothallus red-brown around the aethalium, becoming thinner, membranous and paler (nearly colourless) at the periphery. Cortex thick, smooth, shiny or dull, red-brown on the outer side, inner side pale brownish to cream coloured. Peridia inside the aethalium thin, membranous, white, pale reddish brown or colourless, often somewhat iridescent, forming a pseudocapillitium. Capillitial threads thin, hyaline, connected by mostly elongated and spindle-shaped, or roundish to angular, white to pale reddish brown calcareous nodes. Spores brownish black in mass, brown in transmitted light, globose to subglobose, minutely but distinctly warted, 6.0 7.1-8.5(-9) $\mu \mathrm{m}$ in diameter.

This species has fairly recently been described (Neubert et al. 1995). We re-examined all Fuligo specimens deposited in the Finnish herbaria (H, JOE, KUO, OULU, TUR). Many specimens earlier determined as Fuligo rufa Pers., F. septica var. rufa (Pers.) R.E. Fries, or Fuligo septica (L.) F.H. Wigg. turned out to be F. leviderma. It differs from $F$. septica and its varieties in having a smooth, red-brown or occasionally ochraceous brown cortex, and darker, more distinctly warted spores (Figs. 5, 6, 9).

Neubert et al. (1995) reported Fuligo leviderma growing on Betula, Carpinus, Fagus, Populus, Quercus, and once on Larix and Picea. In Finland it also seems to prefer deciduous trees, especially Populus tremula; one specimen (12.X.1974 MKo) was from living grass.

The species seems to be common in Finland and distributed all over the country.

\section{Fuligo luteonitens L. G. Krieglst. \& Nowotny}

Figs. 7, 10

Specimens examined: Uusimaa. Espoo: Villnäs, on an old Populus tremula trunk, 10.III.1935 EH; Nuuksio National Park, mesic heat spruce forest, on a Populus tremula log (mixed with Leocarpus fragilis (Dicks.) Rostaf., Perichaena sp., Physarum straminipes Lister, and Stemonitis sp.), 20.IX.1994 KP 632A. (H). EteläHäme. Lammi: virgin forest of Kotinen, on decayed wood, 14.IX.1979 MH 1645; on trunk of a dead P. tremula, 07.IX.1982 JM. (H). Kainuu. Sotkamo: Porkkasalo, on $P$. tremula, 02.XI.1991 AM (OULU). Oulun Pohjanmaa. Muhos: Kylmälä, Vapunlantto, Muhosjoki, Vapunniemi, on a fairly well-decayed Pinus sylvestris stump, 29.IX.1998 HH (OULU).

Aethalia subspherical or elongated, yellow to ochraceous yellow, $8-15(-25) \mathrm{mm} \times 17-35(-60) \mathrm{mm}$ in diameter, 6-13 $\mathrm{mm}$ thick. Cortex brittle, yellow to ochraceous yellow, smooth to nearly smooth. Hypothallus not conspicuous. Peridia inside the aethalium hyaline, somewhat shiny, forming a pseudocapillitium. Capilli- 
tium of scanty, short, hyaline, tubular threads, and numerous, small, mostly round to roundish, or occasionally angular or short spindle-shaped white nodes. Spores brownish black to black in mass, greyish brown in transmitted light, globose or more or less oval, with scarce, scattered, irregularly arranged warts, and with a clear paler and thinner area, $6.5-\underline{7.1}-8.0(-8.5)$, or $6 \times 7 \underline{-6.7}$ $\times 7.8-8 \times 8.5(-9) \mu \mathrm{m}$ in diameter.

This species has fairly recently been described from Germany (Neubert et al. 1995). When re-examining all Fuligo specimens deposited in the Finnish herbaria ( $\mathrm{H}, \mathrm{JOE}$, KUO, OULU. TUR) we found six specimens fitting the description of Fuligo luteonitens. It seems to be rarer in Finland than $F$. leviderma. The recently collected specimen from Muhos (Oulun Pohjanmaa) was unidentified, others were earlier identified as Fuligo septica, F. septica var. rufa or F. rufa.

Macroscopically, Fuligo luteonitens may resemble $F$. leviderma and $F$. septica. F. leviderma is usually red-brown, has more abundant and somewhat longer capillitial threads connected with larger, mostly elongated, white to pale reddish brown calcareous nodes, and densely, evenly warted spores without a clear paler area. $F$. septica has a spongy, unsmooth cortex and paler (pale brown to "bright" brown in Hoyer's medium), minutely and more densely warted spores without a clear germ pore (Fig. 8).

Fuligo cf. luteonitens, and other specimens of Fuligo

Specimens examined: Etelä-Häme. Ruovesi: Hyytiälä, Juninmäki, on a decayed trunk of Populus tremula, 6.IX.1956 VH (H). Lammi: S side of the Biological Station, on bark of a dead $P$. tremula, 8.IX.1982 $M H(\mathrm{H})$. Pohjois-Karjala. Lieksa: Kitsinvaara, on Betula, 15.VII.1936 ML (H).

These three specimens are somewhat different from the ones reported above: the cortex, capillitium and pseudocapillitium resemble those of Fuligo luteonitens, but the warts covering the spore wall are not so scarce and dispersed as they are in the six specimens listed under $F$. luteonitens. Also, the colour of the spores is different, resembling that of $F$. leviderma. The specimen from Pohjois-Karjala was earlier identified as F. septica var. candida (Pers.) R.E. Fr., the two others as F. septica.

The majority of the Finnish Fuligo specimens examined proved to belong to Fuligo septica. Some of the specimens can be identified as var. septica, var. candida, var. flava (Pers.) Nann.Bremek. or var. rufa (Pers.) R.E. Fr., but intermediate forms are common. Other Fuligo species occurring in Finland are $F$. cinerea (Schwein.) Morgan, F. intermedia T. Macbr., and F. muscorum Alb. \& Schwein.
Hemitrichia leiotricha (Lister) G. Lister

Specimens examined: Varsinais-Suomi. Vihti: Nuuksio National Park, on a Picea abies log, 15. X.1994 KP 1363; on a big, fallen branch of Betula, KP 1436. (H). Uusimaa. Espoo: Nuuksio National Park, on a fallen branch of $P$. abies, 22.X.1994 KP 1981, 2032A; on a small $P$. abies log, 22.X.1994KP 2024; on a fallen leaf of Betula, 20.X.1994 KP 1714A; on fallen twigs of $P$. abies, KP 2036. (H).

Sporangia dispersed or in small groups, sessile or stalked, globose, yellow, ochraceous yellow or olive-yellow, shiny, $0.3-1.2 \mathrm{~mm}$ tall and $0.3-0.8 \mathrm{~mm}$ in diameter. Stalk, if present, usually short, about $0.1-0.4 \mathrm{~mm}$ long, fairly thick, dark brown to black, filled with refuse matter. Hypothallus dark brown, membranous. Peridium thin, shiny, pale yellow to nearly colourless in transmitted light, usually fairly thinly covered with granular deposits, occasionally thicker, ochraceous brown when granular inclusions are abundant; dehiscing at the upper part. Capillitium yellow, olive-yellow or ochraceous yellow, threads long, simple or sparsely branching, with 35 smooth spirals coiled rope-like, often bent in the middle and halves entangeled together, $3-5 \mu \mathrm{m}$ in diameter, free ends short-pointed. Spores yellow, olive-yellow or ochraceous yellow in mass, pale yellow in transmitted light, globose, minutely spinulose, (9-)10-10.6-12(13) $\mu \mathrm{m}$ in diameter.

Because many authors regard this species only as a variety of Hemitrichia intorta (Lister) Lister, it is difficult to say if it is common, but at least it is widely distributed and reported, e.g., from Europe (Neubert et al. 1993, Lado 1994), the U.S.A. (Martin \& Alexopoulos 1969), India (Lakhanpal \& Mukerji 1981), and Japan (Yamamoto 1998).

\section{Lamproderma gulielmae Meyl. Fig. 4}

Specimens examined: Varsinais-Suomi. Vihti: Nuuksio National Park, on a small, fallen branch of Populus tremula (mixed with Arcyria cinerea (Bull.) Pers. and Trichia sp.), 16.X.1994 KP 1523; on fallen branches of deciduous trees, 16.X.1994, KP 1532, 1533; on fallen leaves of Betula, 16.X.1994 KP 1534. (H). Uusimaa. Espoo: Nuuksio National Park, on a log of Betula (mixed with Didymium melanospermum (Pers.) $\mathrm{T}$. Macbr.), 27.IX.1994 KP 777B, 777C. (H).

Sporangia gregarious, stipitate, globose to obovoid, total height $1.0-2.0 \mathrm{~mm}$, about $0.20-0.40 \mathrm{~mm}$ in diameter, silvery blue, iridescent. Stalk slender, black, 2/3-3/ 4 of the total height, opaque in transmitted light. Hypothallus membranous, discoid, brown. Peridium with conspicuous, dark, more or less sunken spots, separated with pale bands. Columella cylindrical, apex blunt, extending about $1 / 2$ of the head of the sporangium. Capillitium arising from the apex of the columella, threads pallid, straight, somewhat dichotomously branching at the upper parts. Spores dark brown in mass, brown in transmitted light, globose, covered with irregularly arranged, distinct spines, (10.5)-11-11.8-13 $\mu \mathrm{m}$ in diameter, spines usually less than $1 \mu \mathrm{m}$ long. 

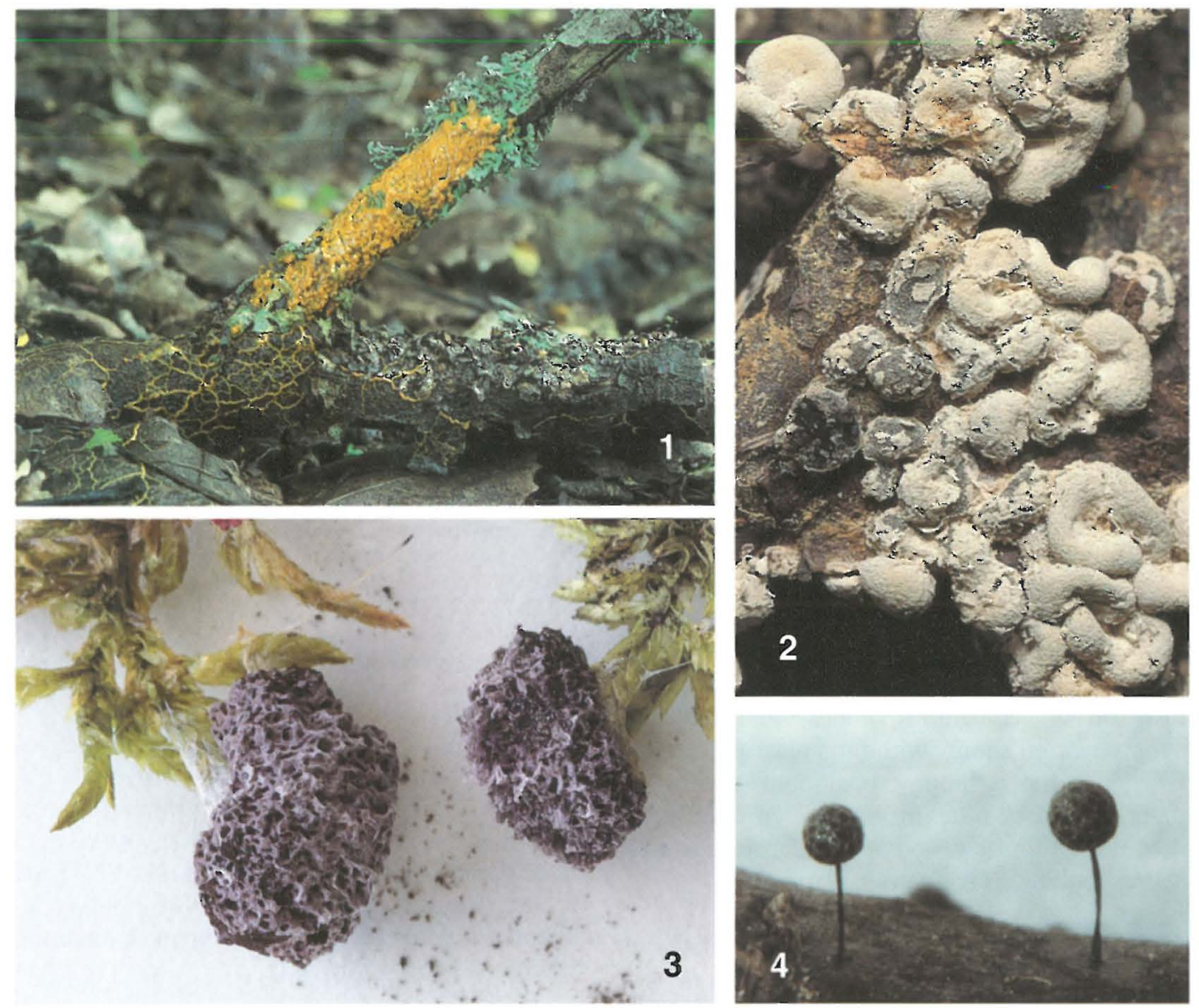

Figs. 1-4. Examples of some species new or rare in Finland. - 1-2. Didymium obducens. Photo Per-Gustav Wikström. 1. Phaneroplasmodium (P-GW 5381). 2. Some sessile, crowded sporangia (P-GW 5397). - 3. Physarum gyrosum (MH 3202), densely crowded sporangia resembling a pseudoaethalium. - 4. Two sporangia of Lamproderma gulielmae (KP 777C).

Figs. 5-10. Fuligo leviderma, F. luteonitens, and F. septica.- 5-6. F. leviderma. 5 . A large $(7 \times 12 \mathrm{~cm})$, flat red-brown aethalium (KP 13). 6. A smaller (13 mm in diameter), more pulvinate aethalium showing the whitish pseudocapillitium (TJH, in 1914). - 7. F. luteonitens, a broken aethalium (KP 632A). - 8. F. septica, the comparatively pale, densely and evenly warted spores $(M H 879)$; bar $=10 \mu \mathrm{m} .-9$. F. leviderma, the relatively dark spores ornamented with minute but distinct warts $(K P 13)$; bar $=10 \mu \mathrm{m} .-10 . F$. luteonitens, the greyish brown spores with scarce, irregularly arranged warts $(K P 632 A) ;$ bar $=10 \mu \mathrm{m}$. 

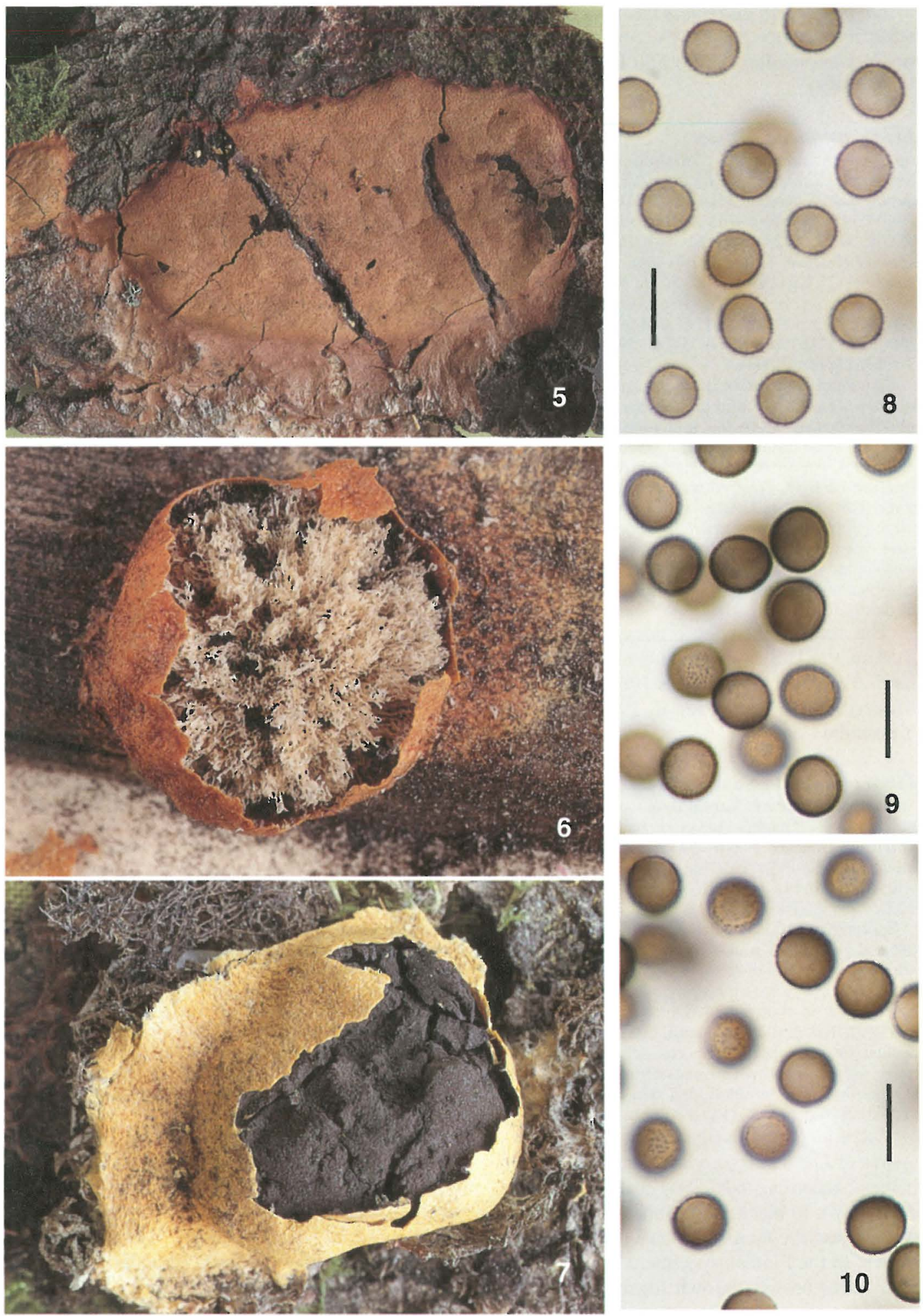
Lamproderma gulielmae has been reported at least from Europe, the U.S.A., and Mexico (Martin \& Alexopoulos 1969, Lado 1994, Rodríguez Palma 1998).

\section{Licea castanea G. Lister \\ Specimens examined: Varsinais-Suomi. Kimito: Skäggböle, Solvalla, on bark of living apple trees (Malus domestica) in garden, 2.II.1999 P-GW 5414; 4.III.1999 P-GW 5418A (mixed with Trichia contorta); 3.III.1999 P-GW 5419, 5420A (mixed with Perichaena chryso- sperma (Currey) Lister and Trichia contorta (Ditmar) Rostaf.), 23.III.1999 P-GW 5431; Kukkulanmäki, on bark of a wild, living apple tree (Malus), 3.III.1999 P- $G W 5421$; Orrnäs, on bark of a wild, living apple tree (Malus), 3.III.1999 P-GW 5422, 5423A (mixed with Trichia contorta). (H). \\ Sporangia scattered or in groups, subglobose, angular or pulvinate, $0.1-0.5 \mathrm{~mm}$ in diameter, or elongated into plasmodiocarps up to $0.9 \mathrm{~mm}$ long, yellow-brown to hazel-brown. Peridium dehiscing along preformed lobes and plates, yellow-brown to hazel-brown, pale yellow in transmitted light, covered with granular material, mar- gins of the lobes and plates with a row of warts. Spores olive-yellow or olive-brown to golden brown in mass, pale yellow or pale olive-brown to yellow-brown in transmitted light, globose, smooth, wall thick with a conspicuous thinner and paler area, (8.5-)9.0-9.9-12 in diameter.}

The species has been reported from Europe, Turkey, the U.S.A., India, Japan and New Zealand (Martin \& Alexopoulos 1969, Lakhanpal \& Mukerji 1981, Neubert et al. 1993, Lado 1994, Yamamoto 1998).

\section{Licea marginata Nann.-Bremek.}

Specimens examined: Varsinais-Suomi. Kimito: Kuggböle, in moist chamber culture on bark of a fallen Picea abies, 25.III.1999 P-GW 5438; Orrnäs, Solvalla, in moist chamber culture on bark of a living Salix (mixed with Macbrideola cornea (G. Lister \& Cran) Alexop.), 10.IV.1999 P-GW 5442. (H).

Sporangia scattered or in small groups, sessile, depressed pulvinate, round to oval when viewed from above, $0.1-0.2 \mathrm{~mm}$ in diameter, ochraceous, dark brown to nearly black, somewhat shiny. Peridium membranous, pale yellow in transmitted light, smooth, usually covered with dark granular material, extending as a dark rim around the sporangium. Spores ochraceous brown in mass, yellowish brown in transmitted light, globose to subglobose, very minutely, but densely, spinulose, not very thick walled, $10-11.2-13 \mu \mathrm{m}$ in diameter.

According to Nannenga-Bremekamp (1991) the spores of Licea marginata are dark, almost black in mass; according to Neubert et al. (1993) they are dark brown to black; and Martin \& Alexopoulos (1969) describe them to be pale rose at first, then brown. In the Finnish specimens the spores were ochraceous brown ("brown sugar") in mass.
Licea marginata has been reported, e.g., from Europe, the U.S.A., and New Zealand (Martin \& Alexopoulos 1969, Gøtzsche 1990, Mitchell 1992, Neubert et. al. 1993, Lado 1994).

Licea operculata (Wingate) G. W. Martin

Specimen examined: Varsinais-Suomi. Kimito: Skäggböle, Solvalla, on bark of Ulmus in moist chamber culture, 9.III.1999 P-GW $5424(\mathrm{H})$.

Sporangia scattered, stipitate, urn-shaped, dark brown, total height $0.5-0.8 \mathrm{~mm}, 0.15-0.18 \mathrm{~mm}$ in diameter. Stalk about two thirds of total height, erect, furrowed, dark brown to nearly black, slightly tapering to the apex, filled with granular deposits. Hypothallus scanty, dark brown. Peridium dark brown, slightly shiny, thinly deposited with refuse matter, pale smoky brown in transmitted light, inner side densely, minutely warted; opening by a membranous, flat operculum which is paler than rest of the peridium, golden yellow, shiny and without refuse matter. Spores yellowish olive in mass, pale yellow, nearly colourless in transmitted light, globose, smooth, fairly thick walled, with a thinner, paler area, $10.5-11-11.5 \mu \mathrm{m}$ in diameter.

In the Finnish specimen the peridium was slightly shiny since it was only thinly deposited with refuse matter. According to the references the peridium (except the lid) is often dull, dark brown to nearly black. Martin \& Alexopoulos (1969) report the spores to be $8-11 \mu \mathrm{m}$ in diameter, while Nannenga-Bremekamp (1991) and Neubert et al. (1995) noted them as 10-13 $\mu \mathrm{m}$.

The species is widely distributed.

\section{Physarum bitectum G. Lister}

Specimen examined: Kainuu. Kuhmo: Vepsä, Teerisuo-Lososuo Reserve, on decayed Populus tremula, 12.X.1992 RV (OULU).

Fructifications gregarious, sessile sporangia, globose to subglobose, $0.6-1.0 \mathrm{~mm}$ in diameter, or mostly plasmodiocarps, $0.6-1.0 \mathrm{~mm}$ wide, and up to $8 \mathrm{~mm}$ long, slightly compressed laterally, rarely branching; white to greyish white. Peridium double, outer layer encrusted with white calcareous granules, shell-like, inner layer thin, pale grey, pale brown in transmitted light; dehiscing irregularly and separately. Columella absent. Capillitium of thin tubular threads connected by abundant, round to roundish, white calcareous nodes. Spores black in mass, dark brown in transmitted light, globose or somewhat crenulate in optical section, irregularly spiny, with smooth, paler areas or pale bands, $8.0-\underline{8.8}-10 \mu \mathrm{m}$ in diameter.

The spore diameter is somewhat smaller than reported in the reference literature $(10-14 \mu \mathrm{m})$. The spore sizes in this study, however, were measured excluding the ornamentation. Physarum bitectum is more common on dead leaves, twigs, straw, compost heaps, etc. than on dead wood (Martin \& Alexopoulos 1969, Nan- 
nenga-Bremekamp 1991, Neubert et al. 1995). This specimen grew on the bark of a dead Populus. It has been reported from Turkey on the bark of a living tree (in moist chamber culture) (Härkönen \& Uotila 1983). It is a widely distributed species, but not common.

\section{Physarum gyrosum Rostaf. Fig. 3}

Specimens examined: Varsinais-Suomi. Kimito: Tavastrona, Högåker, 5.VIII.1998 P-GW 5372 (H). Satakunta. Viljakkala: Hirviniemi, on mosses, 15.VIII.1981 MH 3202, 3203 (H).

Plasmodiocarps crowded, forming rosette-like groups resembling an aethalium, groups about $10-15 \mathrm{~mm}$ long, up to $8 \mathrm{~mm}$ wide and up to $5 \mathrm{~mm}$ high, ash grey. Peridium single, pale brownish or colourless, shiny to iridescent, white peridial lime nearly absent. Columella absent. Capillitium dense, consisting of thin, hyaline tubes with numerous white, spindle-shaped or elongate, spike-like calcareous nodes. Spores dark brown in mass, brown in transmitted light, globose, minutely warted, with some groups of more distinct warts, 7.5- $\underline{8.5}-10 \mu \mathrm{m}$ in diameter.

In the Finnish specimens the peridial lime was nearly absent, but usually the peridium of Physarum gyrosum is covered with white, reddish or rosy calcareous granules (Martin \& Alexopoulos 1969, Nannenga-Bremekamp 1991, Neubert et al. 1995). P. gyrosum has a certain resemblance to some Fuligo specimens without the cortex.

Physarum gyrosum is more common in the tropics than in boreal or temperate zones. In Europe it has mostly been found in greenhouses and gardens (Martin \& Alexopoulos 1969, Nannenga-Bremekamp 1991, Neubert et al. 1995). The type locality is in Germany, from where it has been collected not only from greenhouses and gardens, but once also from a Picea Pinus forest in Judenburg by Gottsberger (Neubert et al. 1995).

Acknowledgements: We wish to thank all the persons who have collected myxomycetes for Finnish herbaria. In particular, we are grateful to Mr. Per-Gustav Wikström, who also lent us photographs of Didymium obducens. We thank the curators of the herbaria JOE, KUO, OULU and TUR for the loans of specimens, and the curators of $\mathrm{H}$ for placing the loans at our disposal. Prof. Uno Eliasson and Prof. Teuvo Ahti revised critically the manuscript, and the English language was revised by Lisa Heidorn.

\section{References}

Gøtzsche, H.F. 1990: Notes on Icelandic Myxomycetes. - Acta Bot. Islandica 10: 3-21.

Hansen, L. \& Knudsen, H. (eds.)1992: Nordic macromycetes 2. - Nordsvamp, Copenhagen. 474 pp.

Hintikka, T. 1920 ("1919"): Révision des myxogastres de Finlande. - Acta Soc. Fauna Flora Fennica 46(9): $1-43$.

Härkönen, M. 1979a: Additions and corrections to Finnish flora of Myxomycetes. - Karstenia 19: 1-7.

Härkönen, M. 1979b: A check-list of Finnish Myxomycetes. - Karstenia 19: 8-18.

Härkönen, M. 1981: Ten Myxomycete species new to Finland. - Karstenia 21: 53-56.

Härkönen, M. 1988: Thirteen taxa of Myxomycetes new to Finland. - Karstenia 28: 93-99.

Härkönen, M. \& Uotila, P. 1983: Turkish Myxomycetes developed in moist chamber cultures. - Karstenia 23: $1-9$.

Karsten, P. 1868: Gastero- et Myxomycetes circa Mustiala crescentes. - Not. Sällsk. Fauna Flora Fennica Förhandl. 9 (n.s. 6): 349-356.

Karsten, P. 1879: Mycologia Fennica 4. - Bidrag Känned. Finlands Natur Folk 31: 89-142.

Lado, C. 1994: A checklist of Myxomycetes of the Mediterranean countries. - Mycotaxon 52: 117-185.

Lakhanpal, T.N. \& Mukerji, K.G. 1981: Taxonomy of the Indian Myxomycetes. - Bibl. Mycol. 78: 1-531.

Martin, G.W. \& Alexopoulos, C.J. 1969: The Myxomycetes. - Univ. Iowa Press, Iowa City. 560 pp.

Mitchell, D.W. 1992: The Myxomycota of the New Zealand and its island territories. - Nova Hedwigia 55: 231-256.

Mitchell, D.W. 1995: The Myxomycota of Australia. Nova Hedwigia 60: 269-295.

Nannenga-Bremekamp, N.E. 1968: Notes on Myxomycetes 14. Remarks on the delimitation of some Arcyria species. - Proc. Kon. Nederlandse Akad. Wetensch. C 71:31-40.

Nannenga-Bremekamp, N.E. 1991: A guide to temperate Myxomycetes. - Biopress, Bristol. 409 pp. (Engl. translation by A. Feest and Y. Burggraaf of De Nederlandse Myxomyceten. 1974. - Kon. Nederlandse Nat. Ver., Zutphen. 460 pp.)

Neubert, H. Nowotny, W. \& Baumann, K. 1993: Die Myxomyceten Deutschlands und des angrenzenden Alpenraumes unter besonderer Berücksichtigung Österreichs 1. Ceratiomyxales, Echinosteliales, Liceales, Trichiales. - Karlheinz Baumann Verlag, Gomaringen. 343 pp.

Neubert, H. Nowotny, W. \& Baumann, K. 1995: Die Myxomyceten Deutschlands und des angrenzenden Alpenraumes unter besonderer Berücksichtigung Österreichs 2. Physarales. - Karlheinz Baumann Verlag, Gomaringen. 368 pp.

Rodríguez Palma, M. 1998: Myxomycetes of the state Tlaxcala. - McIlvainea 13: 25-32.

Yamamoto, Y. 1998: The myxomycete biota of Japan. - Toyo Shorin Publishing Co., Tokyo. 700 pp. 